\title{
COGNITIVE STIMULATION STRATEGY IN THE PROFESSIONAL TRAINING PROCESS
}

\author{
Gloria RAȚA $\breve{1}^{1 *}$, Marinela RAȚ $\breve{A}^{1}$, Bogdan Constantin RAṬ $\breve{A}^{1}$ \\ 1 "Vasile Alecsandri" University, Faculty of Movement, Sports and Health Sciences, Bacău, Romania \\ *Corresponding author: gloria_rata50@yahoo.com
}

DOI: 10.35189/iphm.icpesk.2019.39

\begin{abstract}
The dynamics of the professional training process requires an approach which involves the stimulation of mental processes such as: active attention, perception of information, understanding of information, memorisation of information, reproduction of information and finally its application. During the university studies, the training of the competences required for the teaching profession is an objective which is complex, but also difficult to achieve. The study conducted on 20 students in physical education over a 14-week period aimed at highlighting the possibility of professional skills training through an activity that tracked the students' behaviour and involvement in the lectures and seminars, by assessing the abilities of attention, perception, understanding, memorisation, reproduction of information. By means of a strategy for students to fill out response sheets to assess their level of participation in the lectures and seminars at different times, we managed to improve their behaviour. The drawn conclusions underlined that the use of a questionnaire to stimulate conscious and interested student participation in the lectures over 14 weeks produces an improvement in the ability of attention, perception, understanding, memorisation, reproduction and application of information, thus confirming the hypothesis. The questionnaire-based assessment strategy for the behaviour in the training of the didactic competences ensures the formation of better specialists, but also the possibility of diversifying the approach of the formative educational act.
\end{abstract}

Keywords: stimulation, training, mental processes, profession.

\section{Introduction}

The formative education system aims essentially at the achievement of professional competences specific to the field of sport science and physical education. For this research topic, we started from the following question: How can we train students to teach physical education and sports skills? The analysis and the answer to this dilemma require a specific approach because, in the higher education institutions specialised in teaching, people are trained to become teachers, coaches, instructors, referees, who, in turn, must master the art of education and training of people. Taking into account that physical education is part of the components of general education, influencing the growth and development of the body, improving the motor activity, cognitive and affective processes and fostering socialisation and morality (Raţă, 2009, p. 7), the formation of professional competences represents the essence of the formative act. The professional competence, understood as the teacher's ability to design, direct and organize the contents of the subject/field on the basis of a deep knowledge of the problem to be studied, is formed during the university studies, but also afterwards. The training of professional competences in the field of sport science and physical education is determined by the capitalisation of theoretical achievements in sports practice and the study of the corresponding scientific issue (Platonov, 2015, p. 19), which takes specific aspects determined by the possibilities of both the teacher and student. A teacher must always update the notion of the future training of others by using their arguments and the synthesis of their common experiences and understanding (Şoitu, 1997, p. 103), which will train the student's ability to assimilate the information to be used in life. The American educational psychologist Bruner (1970, p. 54) emphasises that, at any development stage, any topic can be taught successfully under an adequate intellectual form whenever the teacher uses the right method and teaches in a simpler form, so that the subject can progress much easily and more thoroughly for a full understanding of knowledge. Regarding the formation of professional skills, it is not just about giving lectures, but students also need to learn the strategy of assimilation and how to use the information they receive. As far as professional training is concerned, it is constructivist, and the young people get used to learning continuously, independently and in collaboration with others by mutual action, asking, understanding, thinking and doing. Didactic competences, as a result of teaching-learning, are done in practice, and the understanding of what is learnt, as well as the ability to be a teacher in turn, represent a process in which students must be aware of their possibilities, strive, gather information, strategies, methodologies, collaborate with the teacher, who intervenes and stimulates them. Attention, memory, reflection are processes through which the individual's curiosity for a subject in a field can lead to a good understanding of the activity, the creative ability formation and a good perception of what is to be done. 


\section{Problem statement}

Due to the fact that professional training represents a responsible activity involving ways which can be applied according to the possibilities or circumstances, we consider that the topic related to the use of a strategy based on the stimulation of attention, perception, understanding, memorisation, reproduction and application of information through the method of conversation practice aiming to stimulate the improvement of memory and reasoning, encourages the students' response and gets them accustomed to acquiring an operating protocol, which helps them develop their professional competences.

\section{Research questions}

The research aims to verify the hypothesis that the use of a working tool to stimulate conscious and interested student participation during lectures over 14 weeks, represented by a questionnaire, produces an improvement in the ability of attention, perception, understanding, memorisation, reproduction and application of information.

\section{Purpose of the study}

The aim of the research is to demonstrate that, by using an assessment questionnaire during and at the end of the teaching process/ information-sending process for 14 weeks, we can improve the students' professional skills and shape their ability to be more attentive to the information presentation, perception, understanding, memorisation, reproduction and application, which helps them in their training. To offer students the possibility to get and retain as much information as possible, we used lecture, explanation and conversation accompanied by Power Point presentations during teaching. We also want the research results to be the premises underpinning the professional training in which to intervene with other approaches to the training process, whose aim will be to improve mental processes that provide cognition training and education and ultimately good professional training.

\section{Material and Methods}

In the present paper, we used the following research methods: documentation, pedagogical observation method, survey, data recording and processing method, and graphical method.

\section{Research subjects}

Our research included 20 subjects (Table 2), female and male students aged 19-21 with the physical education and sport specialty. In order to be able to record the data, we obtained a written consent from the students, the research being conducted in accordance with the Helsinki Declaration on Human Subjects Testing and with the agreement of the Ethics Committee of the "Vasile Alecsandri" University in Bacău.

\section{Assessment protocol}

The training of the didactic competences was based on an evaluation questionnaire aimed at verifying the student's active participation at the moment of teaching (Table 1).

Table 1. Example: Working questionnaire on participation in the lecture regarding the didactic principles for the initial evaluation with two responses given by 2 students/ Example of two responses from the first lecture

\begin{tabular}{|c|c|c|c|c|c|c|}
\hline \multirow[t]{2}{*}{$\begin{array}{l}\text { Name } \\
\text { initials }\end{array}$} & \multirow[t]{2}{*}{$\begin{array}{l}\text { Have you } \\
\text { paid attention } \\
\text { to what has } \\
\text { been taught? }\end{array}$} & \multirow{2}{*}{$\begin{array}{l}\text { What have } \\
\text { you } \\
\text { perceived? } \\
\text { Present a } \\
\text { keyword }\end{array}$} & \multirow{2}{*}{$\begin{array}{c}\text { What have } \\
\text { you } \\
\text { understood? } \\
\text { Present } 5 \\
\text { keywords to } \\
\text { render the aim } \\
\text { and lecture }\end{array}$} & \multirow{2}{*}{$\begin{array}{c}\text { What have you } \\
\text { memorised? } \\
\text { Present at least } 2 \\
\text { general aspects } \\
\text { related to the } \\
\text { lecture }\end{array}$} & \multirow{2}{*}{$\begin{array}{l}\text { How can you } \\
\text { reproduce it? } \\
\text { Reproduce the } \\
\text { essential points } \\
\text { of the lecture }\end{array}$} & \multirow{2}{*}{$\begin{array}{c}\text { How can you apply it? or } \\
\text { Where can you apply it? } \\
\text { Present how you can } \\
\text { apply theory into practice }\end{array}$} \\
\hline & & & & & & \\
\hline \multirow[t]{2}{*}{ E.S. } & No & $\ldots$ & $\ldots$ & $\ldots$ & $\ldots$ & $\ldots \ldots$ \\
\hline & 0 & 0 & 0 & 0 & 0 & 0 \\
\hline \multirow[t]{2}{*}{ M.M. } & Yes & Respect & $\begin{array}{l}\text { norms, } \\
\text { requirements, } \\
\text { compliance, } \\
\text { direction }\end{array}$ & $\begin{array}{l}\text { compliance with } \\
\text { the principles } \\
\text { and the need to } \\
\text { comply with } \\
\text { them }\end{array}$ & $\begin{array}{l}\text { definition: } \\
\text { classification; } \\
\text { presentation; } \\
\text { requirements of } \\
\text { each principle }\end{array}$ & $\begin{array}{l}\text { In the } 2^{\text {nd }} \text { grade, we can } \\
\text { conduct the didactic } \\
\text { process according to the } \\
\text { accessibility principle so } \\
\text { that children can perform }\end{array}$ \\
\hline & 3 & 3 & 4 & 4 & 4 & 4 \\
\hline
\end{tabular}


The questionnaire was based on 6 short, concise questions from the taught subject, in which we followed the assessment of the students' participation in the lesson and implicitly their preoccupation with the professional training. The 6 questions changed from one lecture to another. For each question, the student was assessed on a 0 to 4 -point scale $(0$ points $=$ no response, 1 point $=$ one test response, 2 points $=$ one partially good response, 3 points $=$ one good response, 4 points $=$ one correct and complete response). The questionnaire was applied during each course, but we only analysed the responses to the first questionnaire (initial evaluation) and the last questionnaire (final evaluation).

\section{Results}

From Table 2, subsequent to the implementation of the formative activity directed to the 6 applied components of the learning process (attention, perception, understanding, memorisation, reproduction and application) and the calculation of the arithmetic mean, standard deviation and maximum and minimum values, we can observe a series of aspects.

Table 2. Results of information perception, understanding, memorisation and application

\begin{tabular}{|c|c|c|c|c|c|c|c|c|c|c|c|c|c|c|c|}
\hline & \multirow{3}{*}{$\begin{array}{c}\text { Item no./ } \\
\text { Name } \\
\text { initials }\end{array}$} & \multicolumn{6}{|c|}{ Results of information perception and understanding } & \multicolumn{6}{|c|}{ Results of information memorisation and application } & \multirow{2}{*}{\multicolumn{2}{|c|}{ Total points }} \\
\hline & & \multicolumn{4}{|c|}{$\begin{array}{lc}\text { active attention } & \begin{array}{c}\text { information } \\
\text { perception }\end{array}\end{array}$} & \multicolumn{2}{|c|}{$\begin{array}{l}\text { information } \\
\text { understanding }\end{array}$} & \multicolumn{2}{|c|}{$\begin{array}{l}\text { information } \\
\text { memorisation }\end{array}$} & \multicolumn{2}{|c|}{$\begin{array}{l}\text { information } \\
\text { reproduction }\end{array}$} & \multicolumn{2}{|c|}{$\begin{array}{l}\text { information } \\
\text { application }\end{array}$} & & \\
\hline & & I & $\mathrm{F}$ & I & $\mathrm{F}$ & I & $\mathrm{F}$ & I & F & I & $\mathrm{F}$ & I & $\mathrm{F}$ & I & $\mathrm{F}$ \\
\hline 1 & E.S.V. & 0 & 3 & 0 & 3 & 0 & 4 & 0 & 4 & 0 & 4 & 0 & 4 & 0 & 3.66 \\
\hline 2 & M.Ma. & 1 & 3 & 1 & 3 & 1 & 3 & 1 & 3 & 1 & 3 & 1 & 3 & 1 & 3.00 \\
\hline 3 & M.Mi. & 2 & 4 & 2 & 4 & 3 & 4 & 3 & 4 & 4 & 4 & 4 & 4 & 3.00 & 4.00 \\
\hline 4 & G.M. & 0 & 2 & 0 & 2 & 0 & 2 & 0 & 2 & 0 & 2 & 1 & 3 & 0.16 & 2.16 \\
\hline 5 & G.G. & 3 & 4 & 3 & 4 & 3 & 4 & 3 & 4 & 2 & 4 & 3 & 4 & 2.83 & 4.00 \\
\hline 6 & C.Ș. & 2 & 3 & 2 & 3 & 2 & 3 & 2 & 3 & 2 & 3 & 3 & 4 & 2.16 & 3.16 \\
\hline 7 & G.B. & 3 & 4 & 3 & 4 & 3 & 4 & 3 & 4 & 3 & 4 & 2 & 4 & 2.83 & 4.00 \\
\hline 8 & D.T.G & 1 & 2 & 1 & 2 & 1 & 2 & 1 & 2 & 2 & 3 & 2 & 3 & 1.33 & 2.33 \\
\hline 9 & R.V.O & 3 & 4 & 3 & 4 & 3 & 4 & 4 & 4 & 4 & 4 & 3 & 4 & 3.83 & 4.00 \\
\hline 10 & S.D.A & 2 & 3 & 2 & 3 & 2 & 3 & 2 & 3 & 2 & 3 & 2 & 4 & 2.00 & 3.16 \\
\hline 11 & C.M. & 3 & 4 & 3 & 4 & 3 & 4 & 3 & 4 & 3 & 4 & 4 & 4 & 3.16 & 4.00 \\
\hline 13 & C.A.A & 3 & 3 & 3 & 3 & 3 & 3 & 3 & 3 & 4 & 3 & 3 & 4 & 3.00 & 3.33 \\
\hline 14 & L.A. & 3 & 4 & 3 & 4 & 3 & 4 & 3 & 4 & 3 & 4 & 2 & 3 & 3.00 & 3.83 \\
\hline 15 & B.A. & 2 & 3 & 2 & 3 & 2 & 3 & 2 & 3 & 2 & 3 & 2 & 4 & 2.00 & 3.16 \\
\hline 16 & M.L.D & 4 & 4 & 4 & 4 & 4 & 4 & 4 & 4 & 4 & 4 & 2 & 4 & 3.66 & 4.00 \\
\hline 17 & V.I.I. & 2 & 3 & 2 & 3 & 2 & 3 & 2 & 3 & 2 & 3 & 2 & 3 & 2.00 & 3.00 \\
\hline 18 & T.M.F & 2 & 4 & 2 & 4 & 2 & 3 & 2 & 3 & 2 & 3 & 3 & 4 & 3.16 & 3.50 \\
\hline 19 & C.G. & 4 & 4 & 4 & 4 & 4 & 4 & 4 & 4 & 3 & 4 & 3 & 4 & 3.66 & 4.00 \\
\hline 20 & N.A. & 0 & 3 & 0 & 3 & 0 & 3 & 0 & 3 & 0 & 3 & 1 & 4 & 0.16 & 3.16 \\
\hline \multicolumn{2}{|c|}{ Mean } & 2.100 & 3.400 & 2.100 & 3.400 & 2.200 & 3.400 & 2.250 & 3.400 & 2.300 & 3.450 & 2.350 & 3.750 & 2.289 & 3.445 \\
\hline \multicolumn{2}{|c|}{ Max. } & 4 & 4 & 4 & 4 & 4 & 4 & 4 & 4 & 4 & 4 & 4 & 4 & 3.83 & 4 \\
\hline \multicolumn{2}{|c|}{ Min. } & 0 & 2 & 0 & 2 & 0 & 2 & 0 & 2 & 0 & 2 & 0 & 3 & 0 & 2.16 \\
\hline \multicolumn{2}{|c|}{ St. dev. } & 1.276 & 0.710 & 1.276 & 0.710 & 1.302 & 0.710 & 1.346 & 0.710 & 1.355 & 0.651 & 1.183 & 0.445 & 1.257 & 0.614 \\
\hline
\end{tabular}

*Marking system (for the situations: attentive/perceived/understood/memorised/reproduced/applied): $0=$ no, $1=$ tried; $2=$ partially performed; 3 = sometimes performed; 4 = permanently performed.

For the arithmetic mean, the following were found:

- active attention in the initial evaluation recorded a value of 2.100 points, and in the final evaluation, 3.400 points, thus a progress of 1.30 points;

- information perception in the initial evaluation recorded a value of 2.100 points, and in the final evaluation, 3.400 points, thus a progress of 1.300 points;

- information understanding in the initial evaluation recorded a value of 2.200 points, and 3.400 points in the final evaluation, thus a progress 1.200 points;

- information memorisation at the initial evaluation recorded 2.250 points, and in the final evaluation, 3.400 points, thus a progress of 1.150 points;

- for reproducing the information, 2.300 points were recorded at the initial evaluation and 3.450 points at the final evaluation, thus a progress of 1.150 points; 
- for applying the information, 2.350 points were recorded at the initial evaluation and 3.750 points at the final evaluation, thus a progress of 1.400 points.

The maximum value in both the initial and the final assessments was 4 points, and the minimum value was 0 (zero) in the initial evaluation and 2 and 3 points in the final evaluation, respectively;

In the standard deviation of the 6 components for assessing the involvement during the lecture, the initial evaluation recorded a value of between 1.427 and 1.231, and in the final evaluation, between 0.710 and 0.445 .

Overall, the 6 components (Table 2) recorded an average of 2.289 in the initial evaluation and 3.445 points in the final evaluation, thus a progress of 1.156 points, a maximum of 3.83 in the initial evaluation and 4.00 points in the final evaluation, a minimum of 0 points in the initial evaluation and 2.16 points in the final evaluation and a standard deviation of 1.257 in the initial evaluation and 0.614 in the final evaluation.

The percentage results calculated for the 6 components (Table 2) highlight the progress of students from the initial to the final evaluation (Table 3).

Table 3. Progress for the 6 components of learning

\begin{tabular}{|c|c|c|c|c|c|c|c|c|c|c|c|c|c|c|c|c|c|c|c|c|c|c|c|c|}
\hline \multirow[t]{3}{*}{ Points } & \multicolumn{4}{|c|}{ active attention } & \multicolumn{4}{|c|}{$\begin{array}{c}\text { information } \\
\text { perception }\end{array}$} & \multicolumn{4}{|c|}{$\begin{array}{l}\text { information } \\
\text { understanding }\end{array}$} & \multicolumn{4}{|c|}{$\begin{array}{l}\text { information } \\
\text { memorisation }\end{array}$} & \multicolumn{4}{|c|}{$\begin{array}{l}\text { information } \\
\text { reproduction }\end{array}$} & \multicolumn{4}{|c|}{$\begin{array}{c}\text { information } \\
\text { application }\end{array}$} \\
\hline & \multicolumn{2}{|c|}{ I } & \multicolumn{2}{|c|}{$\mathrm{F}$} & \multicolumn{2}{|c|}{ I } & \multicolumn{2}{|c|}{$\mathrm{F}$} & \multicolumn{2}{|c|}{ I } & \multicolumn{2}{|c|}{$\mathrm{F}$} & \multicolumn{2}{|c|}{ I } & \multicolumn{2}{|c|}{$\mathrm{F}$} & \multicolumn{2}{|c|}{ I } & \multicolumn{2}{|c|}{$\mathrm{F}$} & \multicolumn{2}{|c|}{ I } & \multicolumn{2}{|c|}{$\mathrm{F}$} \\
\hline & No & $\%$ & no & $\%$ & no & $\%$ & no & $\%$ & no & $\%$ & no & $\%$ & no & $\%$ & no & $\%$ & no & $\%$ & no & $\%$ & no & $\%$ & no & $\%$ \\
\hline 0 & 3 & 15 & 0 & & 3 & 15 & 0 & & 3 & 15 & & & 3 & 15 & & & 3 & 15 & & & 1 & 5 & & \\
\hline 1 & 2 & 10 & & & 2 & 10 & & & 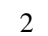 & 10 & & & 2 & 10 & & & 1 & 5 & & & 3 & 15 & & \\
\hline 2 & 7 & 35 & 2 & 10 & 7 & 35 & 2 & 10 & 5 & 25 & 2 & 10 & 5 & 25 & 2 & 10 & 7 & 35 & 1 & 5 & 7 & 35 & & \\
\hline 3 & 6 & 30 & 8 & 40 & 6 & 30 & 8 & 40 & 8 & 40 & 8 & 40 & 7 & 35 & 8 & 40 & 5 & 25 & 9 & 45 & 6 & 30 & 5 & 25 \\
\hline 4 & 2 & 10 & 10 & 50 & 2 & 10 & 10 & 50 & 2 & 10 & 10 & 50 & 3 & 15 & 10 & 50 & 4 & 20 & 10 & 50 & 3 & 15 & 15 & 75 \\
\hline
\end{tabular}

Regarding the active attention for perceiving, understanding and memorising the information (Table 3 and Figure 1), in the initial evaluation, we found the following: a percentage of $15 \%$, i.e. 3 students who received 0 points, a percentage of $10 \%$, i.e. 2 students, 1 point, a percentage of $35 \%$, i.e. 7 students who obtained 2 points, a percentage of $30 \%$, i.e. 6 students who got 3 points, a percentage of $10 \%$, i.e. 2 students who attained 4 points, and in the final evaluation, a percentage of $10 \%$, i.e. 2 students took 2 points, a percentage of $40 \%$, i.e. 8 students acquired 3 points and a percentage of $50 \%$, i.e. 10 students achieved 4 points. The percentage of students (Figure 1) who received 4 points for this component increased by $40 \%$ in the final evaluation compared to the initial one. Large differences are also recorded for those who got 2 points (because their percentage dropped from $35 \%$ to $10 \%$, i.e. by $25 \%$ ), but also for those who obtained 3 points (their percentage increased from $30 \%$ to $40 \%$ ), so we can say that students' attention was improved during the lectures. As it can be seen, the results of the 4 components are almost equal, which is a normal aspect, as the level of attention influences the other components.

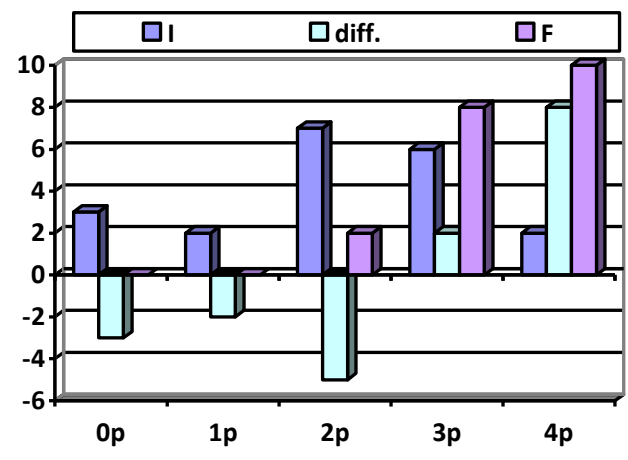

Figure 1. Graphical representation of the evolution of attention, understanding, memorisation

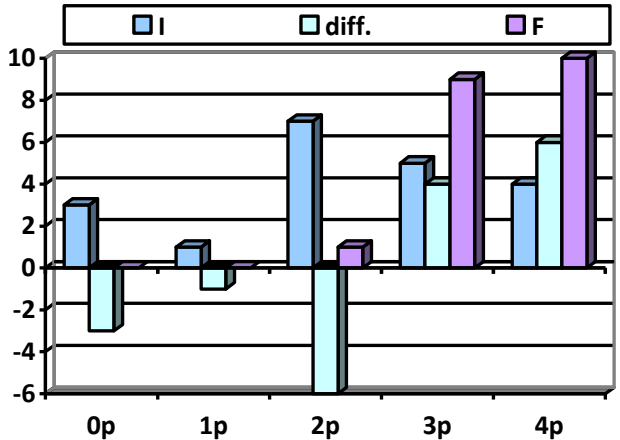

Figure 2. Graphical representation of the evolution of information reproduction

For the information reproduction (Table 3 and Figure 2), in the initial evaluation, we found the following: a percentage of $15 \%$, i.e. 3 students who obtained 0 points, a percentage of $5 \%$ i.e. a student who got 1 point, a percentage of $35 \%$, i.e. 7 students who acquired 2 points, a percentage of $25 \%$, i.e. 5 students who attained 3 points, a percentage of $20 \%$, i.e. 4 students took 4 points, and in the final evaluation, a percentage of $5 \%$ was 
recorded, i.e. a student obtained 2 points, a percentage of $45 \%$, i.e. 9 students obtained 3 points and a percentage of $50 \%$, i.e. 10 students obtained 4 points. The percentage of students (Figure 2) for this component, getting 4 points, increased by $30 \%$ in the final evaluation compared to the initial one. Large differences are also recorded for those who obtained 2 points (because their percentage dropped from 35\% to 5\%, thus by 30\%), but also those who obtained 3 points (their percentage increased from $25 \%$ to $45 \%$ ), so we can say that the students' attention was improved during lectures. As it can be seen, the results of the information reproduction ability have improved at the final evaluation.

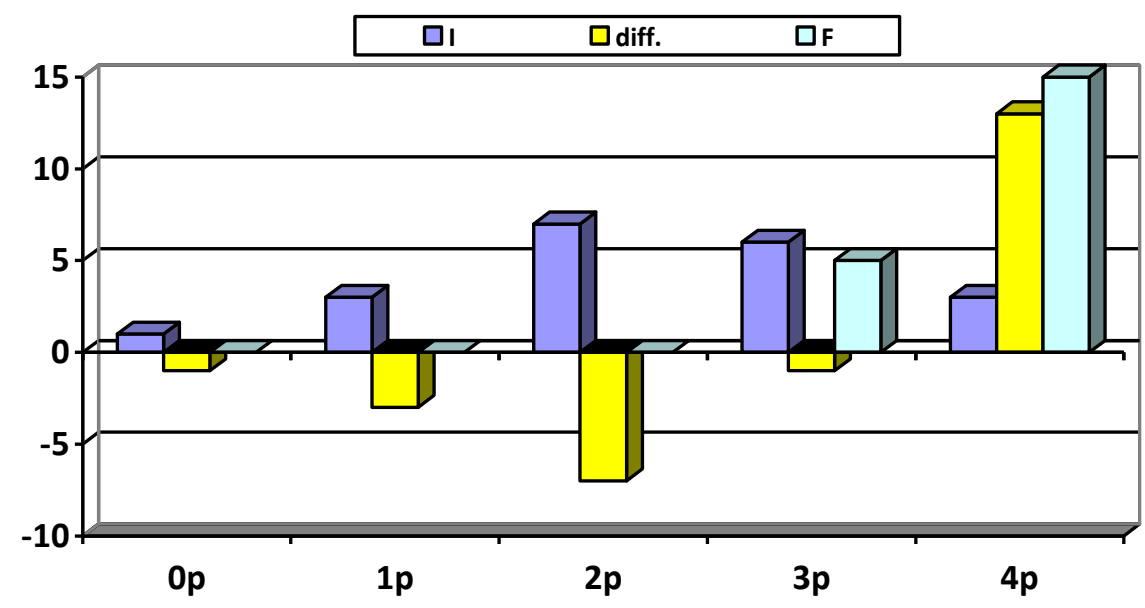

Figure 3. Graphical representation of information application

For the information application (Table 3 and Figure 3), in the initial evaluation, we found the following: a percentage of $5 \%$, i.e. a student who obtained 0 points, a percentage of $15 \%$, i.e. 3 students got 1 point, a percentage of 35\%, i.e. 7 students who acquired 2 points, $30 \%$, i.e. 6 students who attained 3 points, a percentage of $15 \%$, i.e. 3 students achieved 4 points and at the final evaluation, a percentage of $25 \%$, namely five students took 3 points and a percentage of $75 \%$, i.e. 15 students obtained 4 points. The percentage of students (Figure 3) who gained 4 points for this component increased by $60 \%$ in the final assessment compared to the initial one. Differences were also recorded for those who obtained 3 points (their percentage dropped from $30 \%$ to $55 \%$ ), so we can say that the students' ability to apply information during lectures has improved.

\section{Discussion}

The analysis of the results of our research highlights the improvement of attention, perception, understanding, memorisation, reproduction and application of information, which was also underlined by other specialists. Professional training mainly depends on the form of teaching and learning, which must take into account the collective and especially individual particularities of subjects. Al-Thaqib et al. (2018) emphasise an improvement in the cognitive processes, including attention.

Cognition and the strategy used to incorporate new knowledge and make knowledge-based decisions when performing practical activities are focused on processes such as perception, attention, memory and reasoning. Each of these cognitive functions work together in order to integrate new knowledge and create an interpretation of the world around us, but especially to apply the information gathered. (Pascale, 2006) This was revealed by the increased percentage of students who obtained a higher score in the final assessment.

Our concern in this research was to set the operational objectives to improve the students' ability to be aware, to perceive, understand, memorise, reproduce and apply information and thus help them improve their professional skills. Working in this context, an improvement in the students' behaviour was also observed through a strategy that encouraged, directed and controlled them. The teacher must permanently ensure an educational climate that follows the student's overall development, i.e. the development of cognitive, emotional, voluntary, practical applications. The knowledge of this aspect allows improving the level of professional competences emphasised by Ames (1992), who notes that when the teacher focuses on learning, personal overcoming and participation during lectures, we can deal with a climate of professional development, namely, it helps to improve the students' ability 
to apply information, namely to use in practice what they have learned, which has been underlined by the results of our research.

\section{Conclusion}

According to the data analysis, the results on the use of information have improved from the initial evaluation to the final evaluation, which allows us to assert that the participation of students in classes can be influenced by a strategy focused on specific aspects, the environment in which students work, the demanding and encouraging climate, etc. After analysing and interpreting the data obtained, we believe that the new strategy involving the student stimulation plays an important role when aiming at and pursuing the training of specialists. Given the values of cognitive processes as a substratum, we can assume that the hypothesis according to which the use of a working tool to stimulate conscious and interested student participation during lectures over 14 weeks, represented by a questionnaire, produces an improvement in the ability of attention, perception, understanding, memorisation, reproduction and application of information has been confirmed. Therefore, we can state that the strategy for checking and evaluating the students' behaviour in the formation of didactic competences, based on a questionnaire, ensures the preparation of well-trained specialists, able to organize and direct the educational act. We consider it interesting and innovative the possibility of diversifying the approach of the formative educational act which establishes the creative formation of the didactic personalities.

\section{References}

Al-Thaqib, A., Al-Sultan, F., Al-Zahrani, A., Al-Kahtani, F., Al-Regaiey, K., Iqbal, M., \& Bashir, S. (2018). Brain training games enhance cognitive function in healthy subjects. Medical Science Monitor Basic Research, 24, 63-69. https://doi.org/10.12659/msmbr.909022

Ames, C. (1992). Classrooms: Goals, structures, and student motivation. Journal of Educational Psychology, 84(3), 261-271. https://psycnet.apa.org/doi/10.1037/0022-0663.84.3.261

Bruner, J. S. (1970). Procesul educaţiei intelectuale [The process of intellectual education]. București: Editura Ştiințifică.

Pascale, M. (2006, DEC. 18). What are cognitive abilities and skills, and how to boost them? Retrieved from https://sharpbrains.com/blog/2006/12/18/what-are-cognitive-abilities/

Platonov, V. N. (2015) Periodizarea antrenamentului sportiv: Teoria generală și aplicațiile ei practice [Sports training periodisation: General theory and its practical applications]. București: Discobolul.

Rață, C. B. (2009). Atletismul în sistemul școlar [Athletics in the school system]. Iași: PIM.

Şoitu, L. (1997). Pedagogia comunicării [Communication pedagogy]. București: Editura Didactică și Pedagogică. 